\title{
Expression of Neuropeptide-Y-like Immunoreactivity Begins after Adrenergic Differentiation and Ganglionic Synaptogenesis in Developing Bullfrog Sympathetic Neurons
}

\author{
William D. Stofer and John P. Horn \\ Department of Physiology, University of Pittsburgh, School of Medicine, Pittsburgh, Pennsylvania 15261
}

Immunoreactivities for tyrosine hydroxylase (TH) and neuropeptide $Y$ (NPY) were studied in developing sympathetic neurons of bullfrog tadpoles and adults. At stage III, nearly all ganglion cells are positive for TH. This suggests early commitment to ani adrenergic phenotype, the timing of which is analogous to that reported for sympathetic neurons in birds and mammals. During metamorphic stages and in juvenile bullfrogs, the expression of $\mathrm{TH}$ becomes transiently bimodal: many neurons are intensely positive; the remainder are faintly positive. In adult sympathetic neurons, TH expression is more uniform. NPY first appears in a few principal neurons $(<1 \%)$ of paravertebral ganglia 9 and 10 at stage $X I$. The percentage of ganglion cells containing NPY then increases gradually, reaches adult levels $(\sim 55 \%)$ by stage $X X$, and persists at these levels through metamorphosis. The development of NPY expression follows a similar time course in paravertebral ganglion 6. Double-label experiments in latestage tadpoles and juvenile bullfrogs revealed that the intensely TH-positive neurons are negative for NPY. Taken together with recent electrophysiological data (Horn and Stofer, 1990), these results demonstrate that the development of NPY expression begins long after the onset of adrenergic differentiation and ganglionic synapse formation. The present findings also show that cellular levels of TH and NPY can be independently altered, and they suggest that the onset of NPY expression is not linked to maturation of peripheral targets, but rather to some more global event operating synchronously along the rostro-caudal axis.

A critical step during neuronal differentiation is acquisition of the appropriate transmitter phenotype. In addition to the classical transmitters acetylcholine and norepinephrine, many autonomic neurons appear to cmploy ncuropeptides as cotransmitters (Hokfelt et al., 1980; Furness and Costa, 1987). A large body of evidence shows that the cellular expression of various neuropeptides by sympathetic neurons is quite heterogeneous and probably relates to the organization of functional sympathetic subsystems (Lundberg et al., 1982; Lundberg and Hokfelt,

Received Mar. 28, 1990; revised May 7, 1990; accepted May 24, 1990.

This work was supported by a Grant-in-Aid from the Pennsylvania Affiliate of the American Heart Association, by NIH Grant NS21065, and by NIH Research Career Development Award NSO1427. We are grateful to Dr. Eric Frank for advice in the matter of maintaining tadpoles and to Ms. Patricia Wohlfarth for assisting with histochemistry, darkroom work, and animal care.

Correspondence should be addressed to Dr. John P. Horn, Department of Physiology, University of Pittsburgh, School of Medicine, Pittsburgh, PA 15261. Copyright (C) 1990 Society for Neuroscience 0270-6474/90/103305-08\$03.00/0
1983). One of the more prominent neuropeptides in the sympathetic system is neuropeptide Y (NPY). Its structure is highly conserved in vertebrates (Tatemoto, 1982; Minth et al., 1986; Larhammar et al., 1987; Larhammar and Milner, 1988), where its major known function is regulation of the cardiovascular system (Potter, 1988). However, very few studies have examined the developmental regulation of NPY expression by autonomic neurons. In the rat paracervical ganglia, NPY is present at birth, and the proportion of NPY-positive neurons subsequently increases (Sullivan et al., 1988). In the mouse, NPY is already present at embryonic day 11 in enteric neurons of the gut (Branchek and Gershon, 1989). NPY has also been detected in mammalian sympathetic neurons of newborn animals (Fried et al., 1989; Marek and Mains, 1989) and in avian sympathetic neurons prior to hatching (Garcia-Arraras et al., 1989). The present experiments were undertaken for 2 reasons: First, we wanted to determine the onset of NPY expression in devcloping paravertebral sympathetic ganglia. We focused upon ganglia 9 and 10 in the bullfrog because their synaptic organization has been studied in the adult (see Dodd and Horn, 1983; Horn and Stofer, 1989) and the tadpole (Horn and Stofer, 1990). In the adult bullfrog, NPY-like immunoreactivity is selectively expressed by vasomotor sympathetic C-type neurons (Horn et al., 1987). Second, we sought to establish the temporal relationship between the onset of NPY expression and other major developmental events, namely, adrenergic differentiation and ganglionic synaptogenesis in the B and C cell systems (Horn and Stofer, 1990). Understanding the developmental context of NPY expression may provide valuable clues about the mechanisms of its regulation.

The functional organization of the $\mathrm{B}$ and $\mathrm{C}$ cell systems in paravertebral sympathetic ganglia 9 and 10 has recently been summarized (Horn and Stofer, 1989, 1990). However, several points are especially relevant to the present study: First, it should be noted that amphibian sympathetic neurons, unlike those in birds and mammals, synthesize epinephrine rather than norepinephrine as their primary transmitter (Falck et al., 1963; von Euler, 1971). Second, we are unaware of studies that define the acquisition of adrenergic characteristics by developing amphibian sympathetic neurons. When studies of this type have been carried out in birds (Enemar et al., 1965; Kirby and Gilmore, 1976; Rothman et al., 1978) and mammals (De Champlain et al., 1970; Papka, 1972; Cochard et al., 1979; Teitelman et al., 1979), it has been reported that adrenergic differentiation begins near the end of neural crest migration when sympathetic neuroblasts coalesce to form the paravertebral chain ganglia. Finally, the structure of amphibian NPY is unknown, but several lines of evidence suggest that it is a close homolog of mammalian 

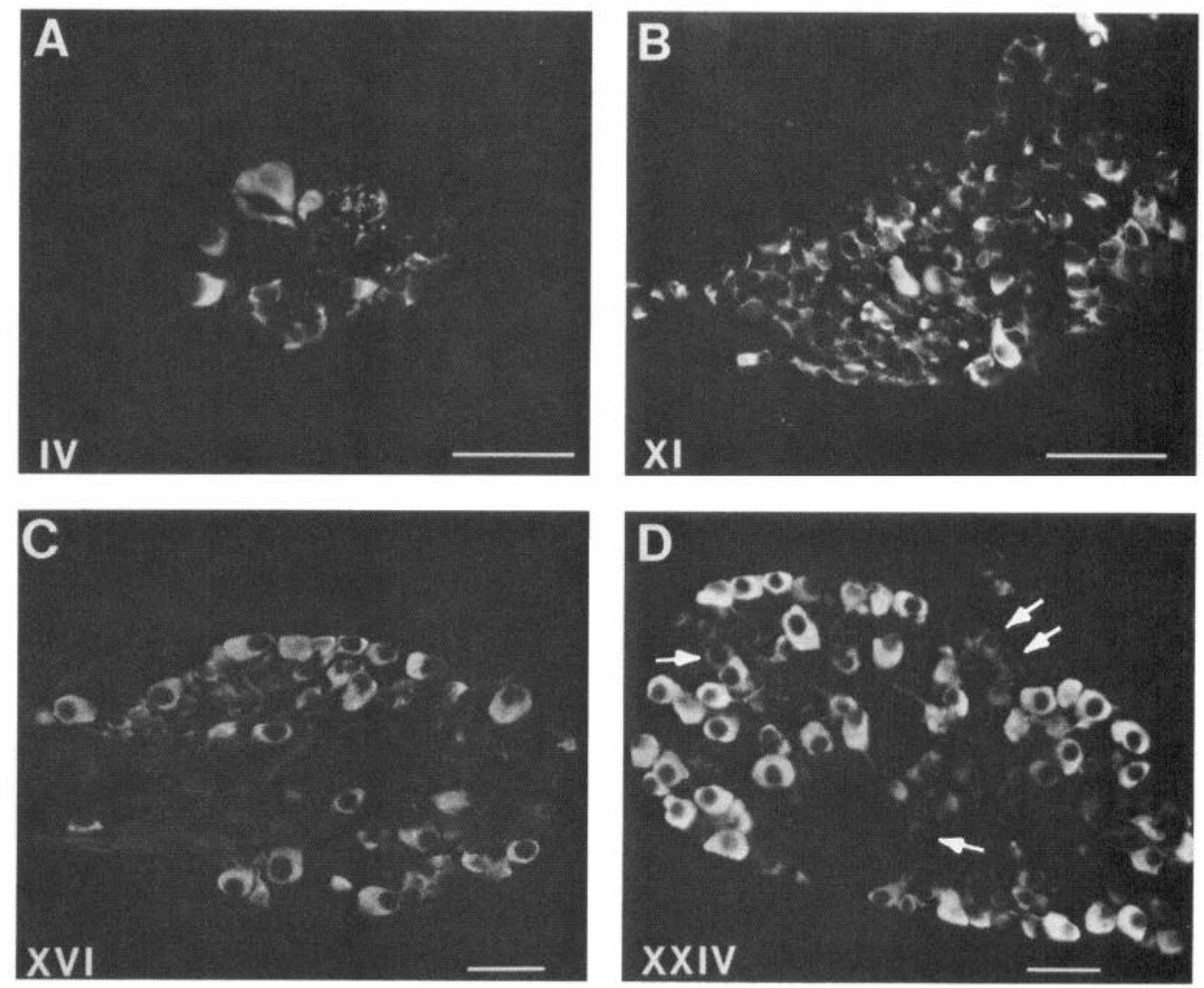

Figure 1. Expression of TH-IR at 4 tadpole stages in sympathetic ganglia 9 and 10. All cell bodies are immunoreactive. Stages are labeled in the lower left corner of each panel. The arrows in $D$ point to examples of faintly stained neurons. Scale bars, $50 \mu \mathrm{m}$.
Preparation of tissue.Tadpoles and juvenile bullfrogs were deeply anesthetized by immersion in $0.4 \%$ tricaine for $15 \mathrm{~min}$, then perfused through the heart with $50 \mathrm{ml}$ cold $4 \%$ paraformaldehyde in $50 \mathrm{~mm} \mathrm{NaCl}$ and $50 \mathrm{~mm} \mathrm{Na}$ phosphate buffer $(\mathrm{pH}, 7.3)$. After perfusion, the viscera were carefully removed so that the aorta and its associated paravertebral sympathetic ganglia remained intact and in place. Blocks of tissue containing the dorsal body wall, vertebral column, aorta, and appropriate sympathetic ganglia were then dissected free and postfixed in $4 \%$ paraformaldehyde for one hr. They were then stored overnight in $25 \%$ sucrose in Na phosphate buffer $(\mathrm{pH}, 7.3)$. Prior to sectioning, blocks were embedded in Tissue-tek (Miles) and immersed in liquid nitrogen for 1 $\mathrm{hr}$. Cryostat sections were cut at $10 \mu \mathrm{m}$, mounted directly onto gelatincoated slides, and stored at $-20^{\circ} \mathrm{C}$ until processing for immunocytochemistry. To examine ganglionic histology, some sections were counterstained with thionin, dehydrated in graded alcohols, cleared in xylenes, and coverslipped.

For experiments on 6 -inch adult bullfrogs, the animals were perfused, then ganglia 9 and 10 were removed and sectioned individually. The details of this procedure have been described previously (Horn et al., 1987).

Immunocytochemistry. Tissue from animals of all ages was processed in the same manner. The solutions, incubations, and wash periods used to stain sections for immunofluorescence have been previously described (Horn et al., 1987; Horn and Stofer, 1988, 1989). Briefly, sections were washed, incubated in primary antibodies overnight at $4^{\circ} \mathrm{C}$, washed 3 times, incubated in secondary antibodies for $30 \mathrm{~min}$ at room temperature, washed 3 times, and coverslipped. For double labeling, sections were incubated first in both primary antibodies, then in both secondary antibodies. The specificities of the 2 primary antibodies, mouse monoclonal anti-tyrosine hydroxylase (TH) (Boehringer; dilution, 1:1000) and rabbit anti-NPY serum (Amersham; dilution, 1:800), have been previously characterized (Rohrer et al., 1986; Horn et al., 1987). The secondary antibodies were goat anti-mouse serum coupled to fluorescein (Cappel; dilution, 1:1000) and goat anti-rabbit serum coupled to rhodamine (Tago; dilution, 1:1000). In addition to previously described controls, the specificity of antibody binding was checked by substituting preimmune sera for both primary antibodies and by reacting primary antibodies with the inappropriate second antibody. All staining was eliminated in each of these controls. 

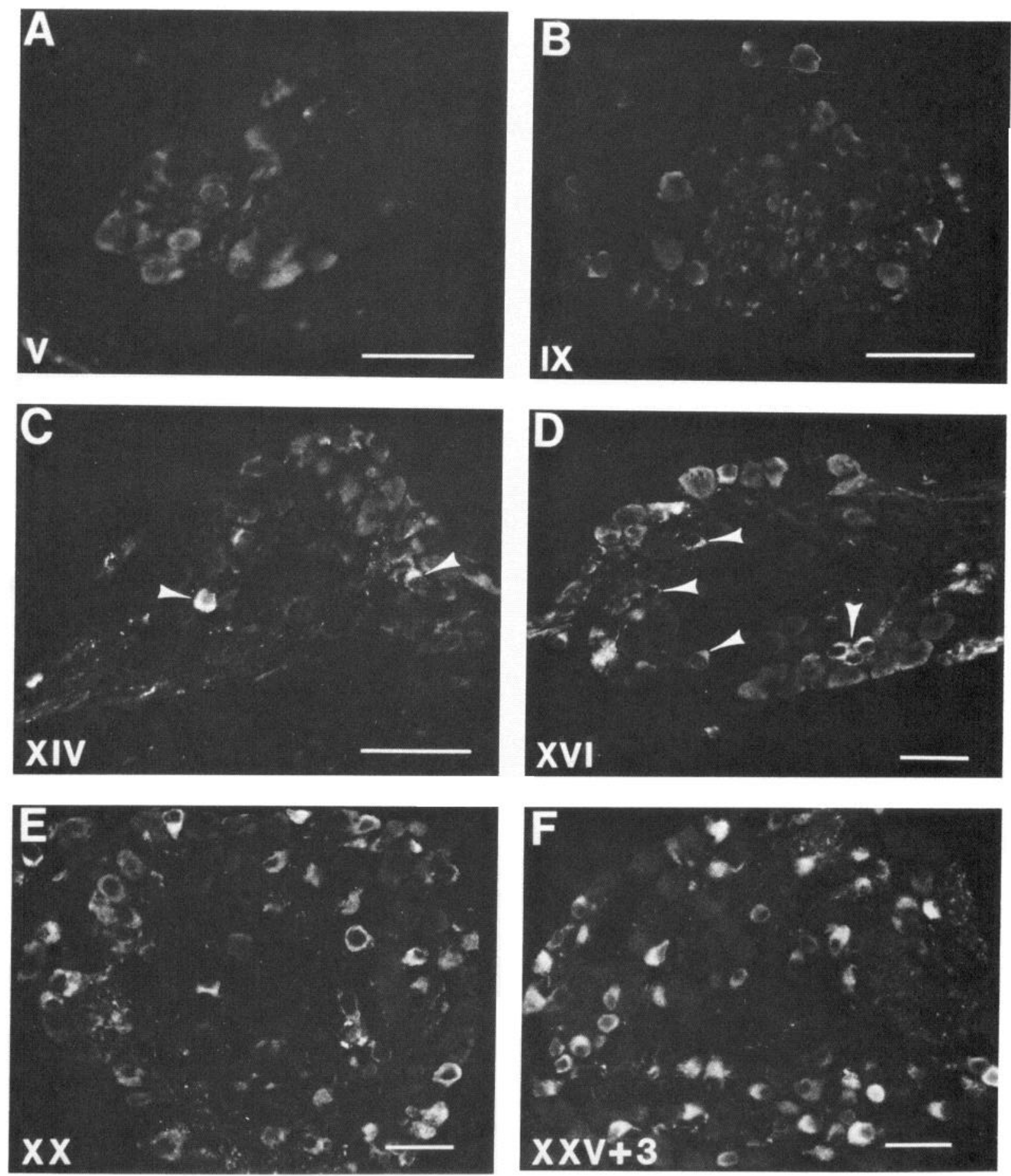

Figure 2. Expression of NPY-IR in ganglia 9 and 10 at 5 tadpole stages $(A-E)$ and in a 3-week-old juvenile bullfrog $(F)$. There is no immunoreactivity in $A$ and $B$. Arrowheads in $C$ and $D$ point to stained neurons. Scale bars, $50 \mu \mathrm{m}$.

\section{Results}

Histology of paravertebral ganglia in tadpoles

The youngest tadpoles that could be obtained for the present study were stage III. Although the gross form of the sympathetic chain had attained its basic adult pattern by this stage, microscopic examination revealed it to be composed of a long, tubelike column of cells, rather than a series of discrete intercon- nected ganglia. Individual ganglia became apparent during subsequent stages. Most ganglion cells at stage III had diameters of less than $10 \mu \mathrm{m}$, but occasional larger cells with diameters greater than $15 \mu \mathrm{m}$ were also present. The range of cell sizes in a stage IV ganglion is illustrated in Figure $1 A$. Axonal processes were evident on cells of all sizes at stage III. However, the fraction of cells having axons could not be discerned from 10$\mu \mathrm{m}$ sections. In Nissl-stained sections, mitotic figures were ev- 


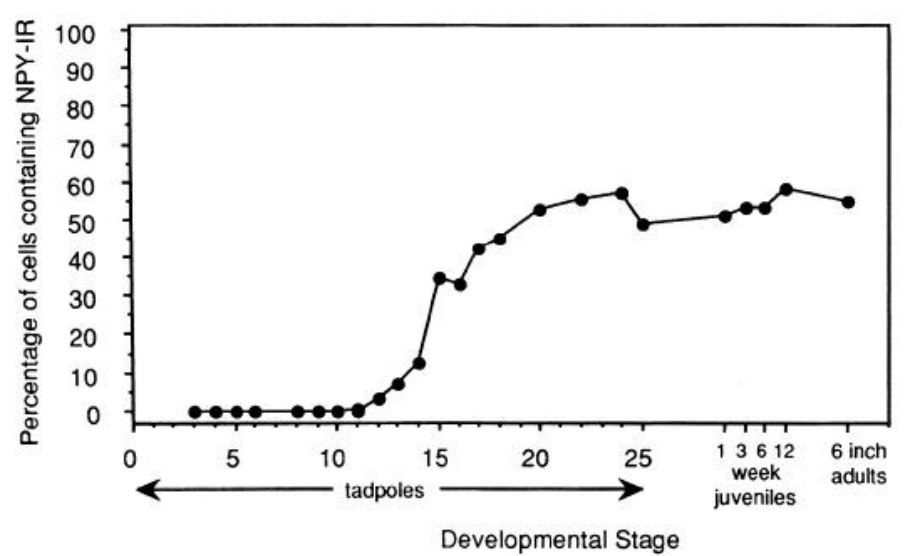

Figure 3. The time course for NPY-IR in sympathetic ganglia 9 and 10. Based on counts from nonadjacent sections, the percentage of NPYIR neurons was estimated in tadpoles and juvenile bullfrogs (see Results). The points at stages V, VI, IX, and XI each represent 2 animals. At other developmental times, the points represent 1 animal per stage. The value for 6 -inch adults ( $n=3$ animals) is taken from Horn et al. (1987).

ident within the ependymal layer of the spinal cord in younger animals, but never within the sympathetic ganglia. Degenerating cells undergoing chromatolysis were not seen in tadpole ganglia.

\section{Immunoreactivity for TH appears early}

In order to assess the acquisition of adrenergic characteristics by individual developing sympathetic neurons, we examined the lumbar paravertebral chain for immunoreactivity to $\mathrm{TH}$ (TH-IR). Previous studies in the rat indicate that expression of
$\mathrm{TH}$ and synthesis of catecholamines begin synchronously in developing sympathetic neurons (Cochard et al., 1979; Teitelman et al., 1979). Moreover, a suitable antibody to TH is readily available (Rohrer et al., 1986).

Immunoreactivity for $\mathrm{TH}$ was characterized by smooth labeling of the perinuclear cytoplasm and of axons (Fig. 1) and appeared early during tadpole development. At stage III and all subsequent stages, the vast majority of cells in ganglia 9 and 10 were positive for TH. Fine TH-positive axons were seen in spinal nerves 9 and 10 at stage IV and in the hindlimb bud at stage V. Based on the expression of TH-IR and the presence of axons, it seems likely that most of the ganglion cells were neurons. Figure $1 A$ illustrates axon hillocks on some TH-positive cells at stage IV. A very small population of tiny, round THnegative cells were also present at stage III and subsequent stages (not shown). It could not be determined whether these infrequent cells were neurons, neuroblasts, or non-neuronal cells. Between stages III and XVI (Fig. 1B,C), the TH-positive cells grew in absolute size, and their cytoplasmic area expanded relative to that of the nucleus.

From about stage XVII onward, it became obvious that the neurons within ganglia 9 and 10 were not all stained for $\mathrm{TH}$ IR with the same intensity (Fig. 1D). In late metamorphic stages $\mathrm{XX}-\mathrm{XXV}$, about half the neurons were intensely positive, and the remainder were faintly positive. During this period, the intensely positive neurons tended to be larger than the faintly positive cells. This bimodal expression of TH-IR persisted for at least 3 months after the completion of metamorphosis. When examined in ganglia from 6 -inch adult bullfrogs, the intensity of TH-IR was somewhat variable, but there was no obvious correlation between staining intensity and cell size (see Fig. $5 F$ ).
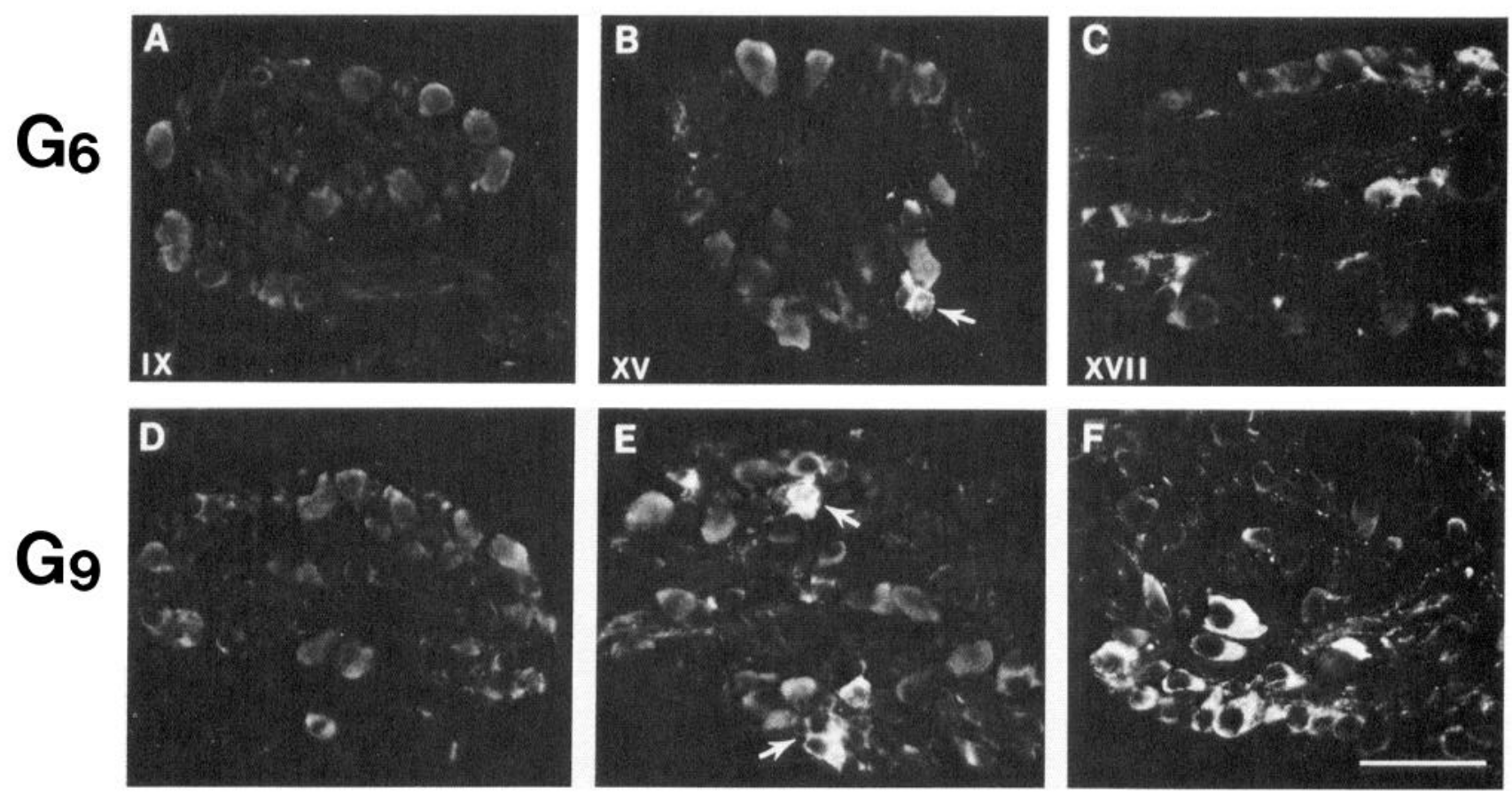

Figure 4. Comparisons of NPY-IR in sympathetic ganglion $6(A-C)$ and ganglion $9(D-F)$. Each pair of ganglia comes from the same animal at a different tadpole stage (marked in the lower left corner of $A-C$ ). In $A$ and $D$, there is no staining. Arrows in $B$ and $E$ point to examples of NPYIR neurons. Scale bar, $50 \mu \mathrm{m}$. 

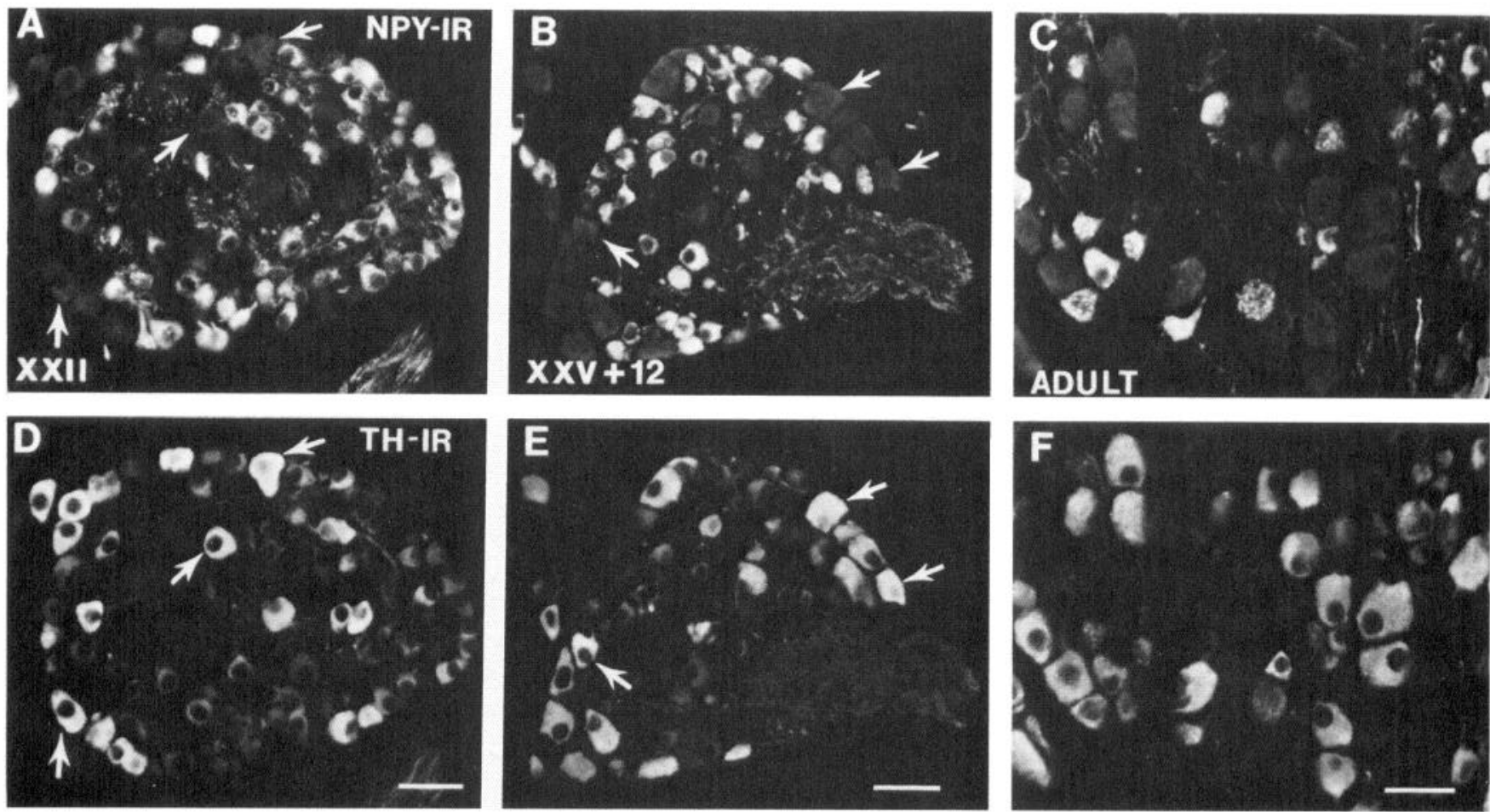

Figure 5. Double labeling for NPY-IR $(A-C)$ and TH-IR $(D-F)$ at stage XXII $(A, D)$, in a 12 -week-old juvenile bullfrog $(B, E)$, and in a 6 -inch adult bullfrog $(C, F)$. Note that in $D$ and $E$, all neurons are positive for TH-IR, but the intensities are bimodal. The brightest cells in these panels are negative for NPY-IR. Arrows point to the same cells in $A$ and $D$ and in $B$ and $E$. Scale bars, $50 \mu \mathrm{m}$.

\section{NPY-IR appears during foot stages}

NPY-IR was not detectable in sympathetic neurons, spinal nerves 9 and 10, or the hindlimbs during limb bud stages III-V (Fig. $2 A$ ) and paddle stages VI-X (Fig. $2 B$ ). The onset of NPY-IR expression occurred in a few neurons at stage XI, which marks the beginning of the foot stages (XI-XVII). Axons containing NPY-IR were first observed in nerve trunks and blood vessels of the hindlimb at stage XII. The proportion of neurons containing NPY-IR increased during subsequent stages and reached a plateau near the beginning of metamorphosis (Fig. 2C-F). Throughout development, NPY-IR had a characteristic granular appearance in the perinuclear cytoplasm and in axons that was identical to previous descriptions in the adult (Horn et al., 1987). The intensity of the immunoreactivity was heaviest in larger neurons that have a larger cytoplasm. In smaller stained neurons with scant cytoplasm, NPY-IR appeared as a faint halo around the nucleus.

In order to quantitate the onset of NPY-IR expression, counts were made of stained and unstained neurons. Nonadjacent sections of ganglia 9 and 10 in tadpoles between stages XI and XXIV and in juvenile bullfrogs that were 1-12 weeks old were photographed, printed at magnifications of $250-400 \times$, and scored for NPY-IR. We counted and scored an average of 686 \pm 360 (SD) cell profiles in 17 animals (range, 214-1427 profiles). Previous experiments have shown that estimates based on this type of sampling are similar to those based on systematic counts of serial sections (Horn et al., 1987; Horn and Stofer, 1988). NPY-IR was first detected at stage XI in 3 of 938 cells $(0.3 \%)$ that were examined in 2 animals. During subsequent stages, the percentage of cells containing NPY-IR progressively increased and reached the adult level of approximately $55 \%$ by stage XX (Fig. 3).

\section{Expression of NPY-IR occurs synchronously along the rostro-caudal axis}

Two possible factors controlling the onset of NPY-IR expression in ganglia 9 and 10 are their segmental position and maturation of their primary targets in the hindlimbs. The onset of NPYIR between stages XI and XX coincides with dramatic development of the hindlimbs and forelimbs. In order to examine these possibilities, a separate series of experiments was performed in which ganglia 6 and 9 were compared in individual tadpoles at stages IX, XV, and XVII. Ganglion 6 was chosen for comparison because it is midway along the neuroaxis and lies between the brachial and lumbar enlargements. It probably innervates targets located in the trunk region rather than in the limbs. The musculature and skin of the trunk differentiate and become functional prior to that of the limbs. The pattern of staining was similar in both ganglia at all 3 stages (Fig. 4). Counts of stained and unstained neurons confirmed that the proportion of immunoreactive neurons was similar at both segmental levels at all 3 stages (Table 1). Therefore, the caudal position of ganglia 9 and 10 at the end of the paravertebral chain and the relatively late development of the hindlimbs are unlikely to account for the onset of NPY-IR.

\section{Heterogeneity of TH expression coincides with NPY-IR expression}

As noted above, levels of TH-IR become transiently bimodal in late metamorphic stages and in juvenile bullfrogs, with the largest cells having the brightest staining. Because the largest 
Table 1. Comparison between ganglia 6 and 9 of developing sympathetic neurons that express NPY-IR

\begin{tabular}{|c|c|c|c|c|c|c|}
\hline \multirow[b]{2}{*}{ Stage } & \multicolumn{3}{|l|}{ Ganglion 6} & \multicolumn{3}{|l|}{ Ganglion 9} \\
\hline & $\begin{array}{l}\text { Number of } \\
\text { cells with } \\
\text { NPY-IR }\end{array}$ & $\begin{array}{l}\text { Total cells } \\
\text { counted }\end{array}$ & $\begin{array}{l}\% \\
\text { positive }\end{array}$ & $\begin{array}{l}\text { Number of } \\
\text { cells with } \\
\text { NPY-IR }\end{array}$ & $\begin{array}{l}\text { Total cells } \\
\text { counted }\end{array}$ & $\begin{array}{l}\% \\
\text { positive }\end{array}$ \\
\hline IX & 0 & 186 & 0.0 & 0 & 522 & 0.0 \\
\hline XV & 60 & 332 & 18.2 & 95 & 514 & 18.5 \\
\hline XVII & 106 & 316 & 33.5 & 497 & 1409 & 35.3 \\
\hline
\end{tabular}

Each stage is represented by a single animal. The data are samples of neurons in ganglia 6 and 9 , not counts of total neurons in the ganglia. Fewer cells were counted in ganglion 6 because it was much smaller than ganglion 9.

neurons in adult ganglia tend to be B cells (Dodd and Horn, 1983) and these neurons do not express NPY-IR (Horn et al., 1987), it was of interest to determine the relation between bimodal TH-IR expression and NPY-IR expression. Sections from late metamorphic tadpoles, juvenile frogs, and adults were therefore double labeled with antibodies to NPY and TH. In tadpoles (Fig. $5 A, D$ ) and juveniles (Fig. $5 B, E$ ), the bright TH-positive neurons were NPY-IR negative, and the dim TH-positive neurons were NPY-IR positive. In ganglia from a 6-inch adult (Fig. $5 C, D)$, TH staining was somewhat variable, and there was no obvious relation between its intensity and the presence of NPYIR.

\section{Discussion}

These experiments define the onset of NPY-IR by developing sympathetic neurons. The results show clearly that the expression of NPY-IR and TH-IR begin at very different times in tadpole development. TH-IR, a marker for adrenergic differentiation, is present in all ganglionic neurons at stage III (Fig. 1), and NPY-IR first appears at stage XI in a few cells (less than $1 \%$ ). Subsequently, the proportion of ganglionic neurons containing NPY-IR increases gradually over several weeks and reaches adult levels $(55 \%)$ by about stage XX (Figs. 2,3). Taken together with recent electrophysiological evidence (Horn and Stofer, 1990), the results also demonstrate that the onset and development of NPY-IR occur after the axons of B- and C-type ganglion cells begin to differentiate and after the onset of nicotinic synapse formation in the ganglia. This implies that phenotypic properties that distinguish subclasses of sympathetic neurons, namcly, action potential conduction velocity, innervation pattern, and neuropeptide expression, are regulated by different mechanisms. Because the onset and development of NPY-IR in ganglion 6 was similar to that in ganglion 9 (Fig. 4, Table 1), it appears unlikely that regulation of NPY-IR is linked to segmental position or to terminal differentiation of postganglionic targets.

The early appearance of TH-IR during tadpole development is consistent with reports in other species (see introductory remarks) where norepinephrine synthesis begins early and is ubiquitous at the time of paravertebral chain formation. It does raise the question, however, of whether TH-IR expression in the tadpole is accompanied by catecholamine synthesis. Although the catecholamine contents of tadpole ganglia were not examined in this work, previous studies indicate that norepinephrine synthesis in rat sympathetic neurons occurs synchronously with initial expression of TH (Cochard et al., 1979; Teitelman et al., 1979). However, it is important to remember that the synthesis of epinephrine by bullfrog sympathetic neurons requires the expression of phenylethanolamine $N$-methyltransferase (PNMT) in addition to $\mathrm{TH}$, L-dopa decarboxylase, and dopamine $\beta$-hydroxylase. In the rat adrenal gland, PNMT does not appear until several days after the expression of TH (Teitelman et al., 1979). One can therefore argue that a similar temporal relation might exist between TH and PNMT expression in bullfrog sympathetic neurons. For these reasons, our data should not be interpreted as evidence for synthesis of epinephrine or for the onset of adrenergic function, but simply as demonstrating the acquisition of a trait essential for adrenergic differentiation.

An unexpected, yet prominent, finding was the transiently bimodal level of TH-IR observed in metamorphic tadpoles and juvenile bullfrogs (Fig. 4D,E). Although TH-IR was quite faint in some cells, we are confident that their staining was above background levels and that our photographs accurately reproduce the range of brightness observed within individual sections. To our knowledge, this phenomenon has not been described in sympathetic neurons of birds and mammals. Nonetheless, previous histochemical studies of catecholamine fluorescence (De Champlain et al., 1970; Yamauchi and Lever, 1971; Eranko, 1972; Papka, 1972) and catecholamine-synthesizing enzymes (Cochard et al., 1979) describe variability of staining intensity. These reports are more reminiscent of our observations in young tadpoles and adult bullfrogs, where no distinct bimodal pattern of staining could be discerned (Fig. $4 F$ ). Another striking aspect of bimodal TH-IR expression was its correlation with the expression of NPY-IR (Fig. 4). NPY-IR-positive neurons stained dimly for TH-IR. Although the significance of these observations is unclear, one intriguing implication is that levels of NPY and catecholamine synthesis can be independently regulated in cells where they are coexpressed. Recent in vitro experiments support this possibility (Marek and Mains, 1989).

Of the many conceivable mechanisms that might produce the transiently bimodal TH-IR, activity is one of the more interesting possibilities. Previous experiments demonstrate that levels of TH expression are transynaptically regulated at least in part by activity (Zigmond, 1980; Black et al., 1981). Based on the fact that those neurons that are very bright for TH-IR do not contain NPY-IR, they are probably B cells (Horn et al., 1987). B cells project to nonvascular targets in the skin (Horn et al., 1988). During the early metamorphic stages when bimodal THIR is first apparent, there is a marked proliferation and maturation of skin glands in the hindlimb (W. D. Stofer, unpublished 
observation). It is therefore tempting to speculate that relatively high levels of TH-IR are stimulated in developing B cells by functional activation of this circuit.

As mentioned above, the $\mathrm{B}$ and $\mathrm{C}$ systems begin to differentiate electrophysiologically before stage XI, when NPY-IR first appears. Elements of both cell systems are evident at stage III, and by stage IX, compound B and C action potentials can be clearly resolved in both preganglionic and postganglionic nerve trunks (Horn and Stofer, 1990). However, the process of ganglionic synaptogenesis is not complete at stage XI or even by stage XX (Marshall, 1982; Dunn and Marshall, 1983; Stofer and Horn, 1989; Horn and Stofer, 1990). It is therefore important to distinguish the general chronology of development from events at the cellular level. Although it seems likely that NPY. IR is selectively expressed by developing $C$ neurons, the present data do not reveal whether individual neurons have expressed other features of $C$ cells at the time they begin to express NPYIR. Specifically, it is not clear whether individual neurons have been innervated and/or have made contact with peripheral blood vessels when they first begin to express NPY-IR between stages $\mathrm{XI}$ and $\mathrm{XX}$.

In addition to synapse formation, numerous other events coincide with the onset of NPY-IR and might therefore influence its expression. Although the hindlimb is little more than a paddle at stage XI, it is already quite complex. Individual muscle masses have differentiated, most peripheral nerve branches and major blood vessels are present, presumptive bones have appeared but remain cartilaginous, and the skin is a simple epithelium. The onset of reflexive movements occurs in the hindlimb around stage IX-X (Letinsky, 1974), just before initial NPY-IR expression. Later, between stages XIV and XVI, skin glands first appear in the proximal hindlimb and then in the distal hindlimb. Interestingly, the onset of NPY-IR coincides with a rise in plasma corticosterone levels (Krug et al., 1983), and the plateau in NPY-IR coincides with increases in circulating thyroid hormones and the onset of metamorphosis (Miyauchi et al., 1977; Suzuki and Suzuki, 1981). The relationship, if any, between these events and the expression of NPY-IR remains to be investigated.

Changes in neuron number may also influence the percentage of neurons expressing NPY-IR during development. One might imagine that the increase in the percentage of cells expressing NPY-IR between stages XI and XX is determined in part by processes of cell division and cell death. Farel and Baek (1989) have recently shown that small numbers of neurons are added to bullfrog sympathetic ganglia in adult life. In the present experiments, mitotic cells were not noted during stages III-XXV. On the other hand, neuronal death is known to reduce cell number during autonomic development (Landmesser and Pilar, 1974; Hendry and Campbell, 1976; Oppenheim et al., 1982; Wright et al., 1983). Degenerating neurons were not noted during the present experiments. In summary, obvious signs of cell addition and death were not observed, but we cannot rule out the possibility that these mechanisms subtly alter the relative sizes of the B and C cell populations during the onset of NPYIR. Another factor that could influence the percentage of cells containing NPY-IR is transient expression by some cells. Although we cannot rule out this possibility, there were no clear signs of this type of phenomenon (i.e., a decrease in the percentage of cells containing NPY-IR). Having focused upon the chronology of TH-IR and NPY-IR expression by populations of sympathetic neurons, the present findings suggest future ex- periments to determine the status and specification of individual sympathetic neurons belonging to different subclasses.

\section{References}

Black IB, Bohn MC, Jonakait GM, Kessler JA (1981) Transmitter phenotypic expression in the embryo. In: Development of the autonomic nervous system, Ciba Foundation symposium 83, pp 177-193. London: Pitman.

Branchek TA, Gershon MD (1989) Time course of expression of neuropeptide $Y$, calcitonin gene-related peptide, and NADPH diaphorase activity in neurons of the developing murine bowel and the appearance of 5-hydroxytryptamine in mucosal enterochromaffin cells. $\mathrm{J}$ Comp Neurol 285:262-273.

Cochard P, Goldstein M, Black IB (1979) Initial development of the noradrenergic phenotype in autonomic neuroblasts of the rat embryo in vivo. Dev Biol 71:100-114.

De Champlain J, Malmfors T, Olson L, Sachs C (1970) Ontogenesis of peripheral adrenergic neurons in the rat: pre- and postnatal observations. Acta Physiol Scand 80:276-288.

Dodd J, Horn JP (1983) A reclassification of B and C neurons in the ninth and tenth paravertebral sympathetic ganglia of the bullfrog. J Physiol (Lond) 334:255-269.

Dunn PM, Marshall LM (1983) Appearance of acetylcholine chemosensitivity during synaptogenesis in frog sympathetic ganglia. Soc Neurosci Abstr 9:689.

Enemar A, Falck B, Hakanson R (1965) Observations on the appearance of norepinephrine in the sympathetic nervous system of the chick embryo. Dev Biol 11:268-283.

Eranko L (1972) Ultrastructure of the developing sympathetic nerve cell and the storage of catecholamines. Brain Res 46:159-175.

Falck B, Haggendal J, Owman C (1963) The localization of adrenaline in adrenergic nerves in the frog. Q J Exp Physiol 48:253-257.

Farel PB, Baek JK (1989) Neuron number increases in postmetamorphic bullfrogs: sympathetic ganglia. Soc Neurosci Abstr 15:301.

Fried G, Meister B, Wikstrom W, Terenius L, Goldstein M (1989) Galinin-,neuropeptide $Y$ - and enkephalin-like immunoreactivities in catecholamine-storing paraganglia of the fetal guinea pig and newborn pig. Cell Tiss Res 255:495-504.

Furness JB, Costa M (1987) The enteric nervous system. New York: Churchill Livingstone.

Garcia-Arraras JE, Lugo AM, Medina L, Martinez R (1989) Expression of neuroactive substances in the developing chick sympathoadrenal system. Soc Neurosci Abstr 15:1016.

Hendry IA, Campbell J (1976) Morphometric analysis of rat superior cervical ganglion after axotomy and nerve growth factor treatment. J Neurocytol 5:351-360.

Hokfelt T, Johansson $\mathrm{O}$, Ljungdahl A, Lundberg JM, Schultzberg $M$ (1980) Peptidergic neurones. Nature 284:515-521.

Horn JP, Stofer WD (1987) Identification in isolated preparations of receptors for 3 putative co-transmitters that may be released by vasomotor sympathetic C neurons in the bullfrog. Neuroscience [Suppl] 22:336.

Horn JP, Stofer WD (1988) Double labeling of the paravertebral sympathetic $C$ system in the bullfrog with antisera to LHRH and NPY. J Auton Nerv Syst 23:17-24.

Horn JP, Stofer WD (1989) Preganglionic and sensory origins of calcitonin gene-related peptide-like and substance P-like immunoreactivities in bullfrog sympathetic ganglia. J Neurosci 9:2543-2561.

Horn JP, Stofer WD (1990) Expression of NPY-like immunoreactivity begins after initiation of nicotinic synapse formation in developing sympathetic ganglia of the bullfrog tadpole. Ann NY Acad Sci, in press.

Horn JP, Stofer WD, Fatherazi S (1987) Neuropeptide Y-like immunoreactivity in bullfrog sympathetic ganglia is restricted to $C$ cells. J Neurosci 7:1717-1727.

Horn JP, Fatherazi S, Stofer WD (1988) Differential projections of B and $C$ sympathetic axons in peripheral nerves of the bullfrog. J Comp Neurol 278:570-580.

Kirby KL, Gilmore SA (1976) A correlative histofluorescence and light microscopic study of the formation of the sympathetic trunks in chick embryos. Anat Rec 186:437-449.

Krug EC, Honn KV, Battista J, Nicoll CS (1983) Corticosteroids in serum of Rana catesbeiana during development and metamorphosis. Gen Comp Endocrinol 52:232-241. 
Landmesser L, Pilar G (1974) Synaptic transmission and cell death during normal ganglionic development. J Physiol (Lond) 241:737749.

Larhammar D, Milner RJ (1988) Strong evolutionary conservation of neuropeptide $Y$ and the carboxyterminal peptide of the neuropeptideY precursor (CPON). Soc Neurosci Abstr 14:1249.

Larhammar D, Ericsson A, Persson H (1987) Structure and expression of the rat neuropeptide Y gene. Proc Natl Acad Sci USA 84:20682072.

Letinsky MS (1974) The development of nerve-muscle junctions in Rana catesbeiana tadpoles. Dev Biol 40:129-153.

Lundberg JM, Hokfelt T (1983) Coexistence of peptides and classical neurotransmitters. Trends Neurosci 6:325-333.

Lundberg JM, Hokfelt T, Anggard A, Terenius L, Elde R, Markey K, Goldstein M, Kimmel J (1982) Organizational principles in the periphcral sympathetic ncrvous system: subdivision by cocxisting peptides (somatostatin-, avian pancreatic polypeptide-, and vasoactive intestinal polypeptide-like immunoreactive materials). Proc Natl Acad Sci USA 79:1303-1307.

Marek KL, Mains RE (1989) Biosynthesis, development, and regulation of neuropeptide $\mathrm{Y}$ in superior cervical ganglion culture. J Neurochem 52:1807-1816.

Marshall LM (1982) Early events in synapse formation on sympathetic neurons of the frog. Soc Neurosci Abstr 8:866.

Minth CD, Andrews PC, Dixon JE (1986) Characterization, sequence, and expression of the cloned human neuropeptide $Y$ gene. J Biol Chem 26:11974-11979.

Miyauchi H, LaRochelle FT Jr, Suzuki M, Freeman M, Frieden E(1977) Studies on thryoid hormones and their binding in bullfrog tadpole plasma during metamorphosis. Gen Comp Endocrinol 33:254-266.

Morris JL, Gibbins IL, Campbell G, Murphy R, Furness JB, Costa M (1986) Innervation of the large arteries and heart of the toad (Bufo marinus) by adrenergic and peptide-containing neurons. Cell Tiss Res 243:171-184.

Oppenheim RW, Maderdrut JL, Wells DJ (1982) Cell death of motoneurons in the chick embryo spinal cord. VI. Reduction of naturally occuring cell death in the thoracolumbar column of Terni by nerve growth factor. J Comp Neurol 210:174-189.
Papka RE (1972) Ultrastructural and fluorescence histochentical studics of devcloping sympathetic ganglia in the rabbit. Am J Anat 134: 337-364.

Potter EK (1988) Neuropeptide $Y$ as an autonomic transmitter. Pharmacol Ther 37:251-273.

Rohrer H, Acheson AL, Thibault J, Thoenen H (1986) Developmental potential of quail dorsal root ganglion cells analyzed in vitro and in vivo. J Neurosci 6:2616-2624.

Rothman TB, Gershon MD, Holtzer H (1978) The relationship of cell division to the acquisition of adrenergic characteristics by developing sympathetic ganglion cell precursors. Dev Biol 65:322-341.

Stofer WD, Horn JP (1989) Development of neuropeptide expression in sympathetic ganglia of the bullfrog tadpole; evidence for specification by the periphery. Soc Neurosci Abstr 15:1016.

Sullivan KA, Papka RE, Traurig HH (1988) Comparison of neurotransmitter appearance in the paracervical ganglion and uterine cervix of the female rat during development. Soc Neurosci Abstr 14:1019.

Suzuki S, Suzuki M (1981) Changes in thyroidal and plasma iodine compounds during and after metamorphosis of the bullfrog, Rana catesbeiana. Gen Comp Endocrinol 45:74-81.

Tatemoto K (1982) Neuropeptide Y: complete amino acid sequence of the brain peptide. Proc Natl Acad Sci USA 79:5485-5489.

Taylor AC, Kollros JJ (1946) Stages in the normal development of Rana pipiens larvae. Anat Rec 94:7-23.

Teitelman G, Baker H, Joh TH, Reis DJ (1979) Appearance of catecholamine-synthesizing enzymes during development of rat sympathetic nervous system: possible role of tissue environment. Proc Natl Acad Sci USA 76:509-513.

von Euler US (1971) Adrenergic neurotransmitter functions. Science 173:202-206.

Wright LL, Cunningham TJ, Smolen AJ (1983) Developmental neuron death in the rat superior cervical sympathetic ganglion: cell counts and ultrastructure. J Neurocytol 12:727-738.

Yamauchi A, Lever JD (1971) Correlations between formal fluorescence and acetylcholinesterase (AChE) staining in the superior cervical ganglion of normal rat, pig and sheep. J Anat 110:435-443.

Zigmond RE (1980) The long-term regulation of ganglionic tyrosine hydroxylase by preganglionic nerve activity. Fed Proc 39:3003-3008. 